\title{
Does the Date of Burning Affect Carbon and Nutrient Losses in a Humid Savanna of West Africa?
}

\author{
Aya B. N'Dri ${ }^{1} \&$ Louis N. Konan ${ }^{1}$ \\ ${ }^{1}$ UFR des Sciences de la Nature, Station d'Ecologie de Lamto/CRE, Pôle de Recherche Environnement et \\ Développement Durable, Université Nangui Abrogoua, 02 BP 801 Abidjan 02, Côte d'Ivoire \\ Correspondence: Brigitte A. N'Dri, UFR des Sciences de la Nature, Station d'Ecologie de Lamto/CRE, Pôle de \\ Recherche Environnement et Développement Durable, Université Nangui Abrogoua, 02 BP 801 Abidjan 02, Côte \\ d’Ivoire. Tel: 225-0807-4528. E-mail: ndri.brigitte@yahoo.fr/ndribrigitte.sn@univ-na.ci
}

Received: July 18, 2018

doi:10.5539/enrr.v8n3p102
Accepted: August 28, 2018

URL: https://doi.org/10.5539/enrr.v8n3p102

\begin{abstract}
A significant impact of fires is the transfer to the atmosphere of the elements contained in combusted biomass. This study was carried out in the Guinean savanna of Lamto (Côte d'Ivoire) to evaluate fire-mediated carbon and nutrient losses from biomass according to the date of burning. The fire regimes tested consisted of three different burning dates: early (EF), mid (MF), and late (LF) season fires, on nine 0.5 ha plots. Carbon and five elemental nutrients were assessed in the aboveground biomass prior to burning and in ash and unburnt biomass after fires; losses were assessed by subtraction. The proportion of nutrients transferred to the atmosphere varied from $42 \%$ (K) to $98 \%(\mathrm{C})$. The lowest losses were recorded during the EF and the greatest during the MF and LF. Emission of $\mathrm{CO}_{2}$ was relatively greatest during the EF than during the MF and LF $\left(16,14\right.$ and $13 \mathrm{t} \mathrm{ha}^{-1}$ respectively). The proportion of the fine ash fraction $(<1 \mathrm{~mm})$ was the greatest during MF. The highest concentrations of $\mathrm{K}, \mathrm{P}, \mathrm{Ca}$ and $\mathrm{Mg}$ occurred in this fraction, most susceptible to losses due to wind and rainfall. The percentage losses of $\mathrm{C}, \mathrm{N}$ and $\mathrm{K}$ were positively correlated with fire maximal temperatureand flame height, explaining the relatively higher losses during MF. Over the long term, the MF applied annually, would lead to important depletion of soil nutrients, particularly $\mathrm{N}$ and $\mathrm{P}$, which contributes to the low availability of nutrients in the soils of Lamto savannas.
\end{abstract}

Keywords: ash, biomass burning, burning dates, nitrogen, nutrients losses.

\section{Introduction}

Biomass burning is recognized as a significant source of greenhouse gases, which significantly impacts global atmospheric chemistry and climate change (Reid et al., 2005; Tunved et al., 2006). According to Shi et al. (2015), global annual $\mathrm{CO}_{2}$ emissions range from 6521.3 to $9661.5 \mathrm{Tg}_{\text {year }}{ }^{-1}$, with a high proportion arising from tropical regions of Africa, South America and Southeast Asia. Globally, a great fraction of these emissions is released by the burning of savannas, followed by forests and croplands (Andreae, 1991; NASA, 2005). However, there is a large uncertainty on the exact $\mathrm{CO}_{2}$ emissions during savanna fires as estimates differ according to the specific methodologies used (Ellicott et al., 2009). Accurate estimates of $\mathrm{CO}_{2}$ emissions from biomass burning at local and regional levels are urgently needed to refine global estimations and better understand the impact of fire on climate. Thus, fires in African savannas are an essential factor of the global $\mathrm{CO}_{2}$ balance. Moreover, numerous studies view the West African savanna as one of the important "burn centers" of the planet (Menaut, 1993; Liousse et al., 2004; NASA, 2005). Our study aims at making up for the scarcity (Helas et al., 1995) of quantitative assessments of $\mathrm{CO}_{2}$, carbon and nutrients emissions from savanna fires in West Africa.

Fire has a marked effect on nutrient balance and cycling in ecosystems (O'Connell et al., 1981) since a significant fraction of nutrients is lost directly to the atmosphere during fires by volatilization (non-particulates, gaseous emissions) and by entrained ash and vegetation fragments that are displaced by winds (particulate emissions) (Rossiter-Rachor et al., 2008). Particulate emissions may be redeposited within several kilometers of a fire. Non-particulate losses represent permanent losses from burnt sites since these losses are redistributed world-wide (Rossiter-Rachor et al., 2008). Many nutrients such as N, P, K and Mg are lost by volatilization under gaseous form, while calcium is lost mainly through ash particle transport (Raison et al., 1985a; Cook, 1994). Further indirect losses may result from erosion of ash and soil (Bodí et al., 2014). 
The proportion of transferred carbon and nutrients largely depends on fire intensity that affects both vaporization temperatures and the amount of ash produced (Raison et al., 1985b; Coutinho, 1990; Koné, 2012). Fire intensity is in turn influenced by fuel characteristics (load and moisture content) and weather during fire (Hoffmann et al., 2012; N'Dri et al., 2018a). Thus, the magnitude of nutrient losses during fires is strongly influenced by factors depending on the timing of the burning during the seasonal cycle (vegetation state and weather).

The quantification of the impact of fire regime, i.e. the frequency and timing of burning, on carbon and nutrient losses during fires, and the study of the determinants of these nutrient losses in humid savannas of West Africa have received little consideration, despite the importance of fire as a land management tool in this region where fire is more frequent and intense than in dry savannas, due to higher grass production. Fire commonly occurs annually in the middle of the dry season in humid savannas of West Africa (Innes, 1972). However, significant woody plant encroachment was reported in this area (Gautier, 1990; Heubes et al., 2011). Fires play a critical role in this type of savanna to control tree demography (Bond \& Keely, 2005): they increase the mortality of saplings and decrease their growth by repeating killing their aboveground part, forcing them into a resprouting habit before they get taller than average flame height, usually around $2 \mathrm{~m}$ high. Thus, other fire regimes are currently tested (early and late fire: N'Dri et al., 2018a) in order to find out the best fire regime to reduce tree density. However, while little is known about the losses of carbon and nutrients during the usual mid-season fire, nothing is known about these losses and $\mathrm{CO}_{2}$ emission during the early and late fires. This should be studied because fire regimes may threaten soil fertility in the long term by causing nutrient unbalance, for example if early or late fire leads to higher carbon and nutrient losses than mid-season fire. The aim of this study was thus to quantify the losses of carbon and nutrients from grass biomass burning under different fire regimes defined by the date of burning (early, mid-season and late fires), to estimate $\mathrm{CO}_{2}$ emission during fires, and to determine the factors, i.e. fuel load, fire and weather characteristics, that determine the magnitude of losses of carbon and nutrients.

\section{Material and Methods}

\subsection{Site Description}

The study was carried out in the Lamto Reserve (central Côte d'Ivoire: $6^{\circ} 9$ and $6^{\circ} 13^{\prime} \mathrm{N},-5^{\circ} 15$ and $-4^{\circ} 57$ ' W), a 2500 ha area of typical Guinean forest-savanna mosaic devoted to scientific research since 1962 (Abbadie et al., 2006). The main savanna type is a shrubby savanna with tree cover between $7 \%$ and $62 \%$ (Gautier, 1990). The savanna is dominated by three species of Andropogoneae grasses: Andropogon ascinodis C. B. Cl., Andropogon canaliculatus (Schumach.), and Andropogon schirensis (Hochst. ex A. Rich). Annual aboveground grass net primary production can be as high as $20 \mathrm{tha}^{-1} \mathrm{yr}^{-1}$ (dry mass) (Gignoux et al., 2006).

The average annual rainfall is about $1,200 \mathrm{~mm}$ (Pagney, 1988). The climate is sub-equatorial with four seasons: a long rainy season from mid-March to July, a short dry season in August, a short rainy season from September to mid-November, and a long dry season from mid-November to mid-March. The annual rainfall during the study period (2014) was $991.9 \mathrm{~mm}$, and the temperature averaged $28.8^{\circ} \mathrm{C}$. December and February were the driest months (Figure 1). Rainfall and temperature data were obtained from the Lamto Geophysical Station nearby the study site ( 0.2 to $1 \mathrm{~km}$ off the study plots). Averaged wind speed in the region is generally low: $0.6 \mathrm{~m} \mathrm{~s}^{-1}$ (Le Roux, 1995). Soils are Oxisols with granite as the main bedrock. The upper soil layer is generally sandy textured (60 \% to $80 \%$ sand). Clays consist of illites and slightly crystallized kaolinites with a low adsorption capacity (Riou, 1974). Fires in the Lamto reserve is set by managers at the middle of the long dry season (mid-season fire), following practices of local populations.

\subsection{Experimental Set-Up and Fire Treatments}

Study was conducted on three $230 \times 120 \mathrm{~m}$ blocks of shrubby savanna, each separated from the surrounding similar savanna by a $10-\mathrm{m}$ wide firebreak, and distant from each other by a few kilometers (Figure 2). Each block was divided into three $100 \mathrm{~m} \times 50 \mathrm{~m}$ plots separated from each other by $30 \mathrm{~m}$-wide firebreaks. Each plot in a block received one of three fire treatments in a full factorial design: (1) early fire (EF) at the start of the long dry season $\left(\sim 18^{\text {th }}\right.$ November), (2) mid-season fire (MF) at the middle of the long dry season $\left(\sim 18^{\text {th }}\right.$ January), and (3) late fire (LF) at the very end of the long dry season $\left(\sim 15^{\text {th }}\right.$ March) (Figure 3). All blocks were located on a flat ground to eliminate the influence of slope on fire behaviour. All plots had experienced annual mid-season fire for at least 50 years before the experiment. 


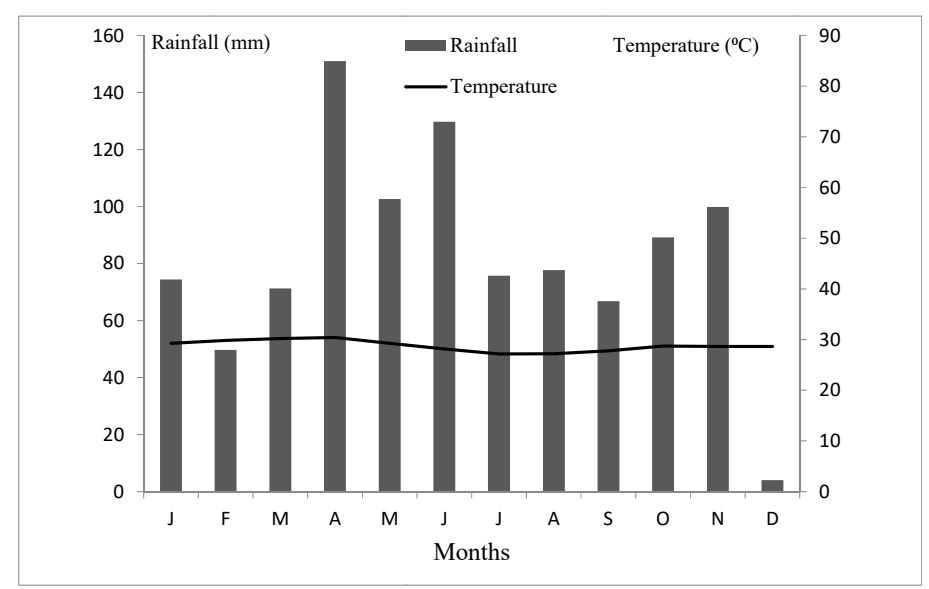

Figure 1. Monthly rainfall and air temperature over the year of study (2014)

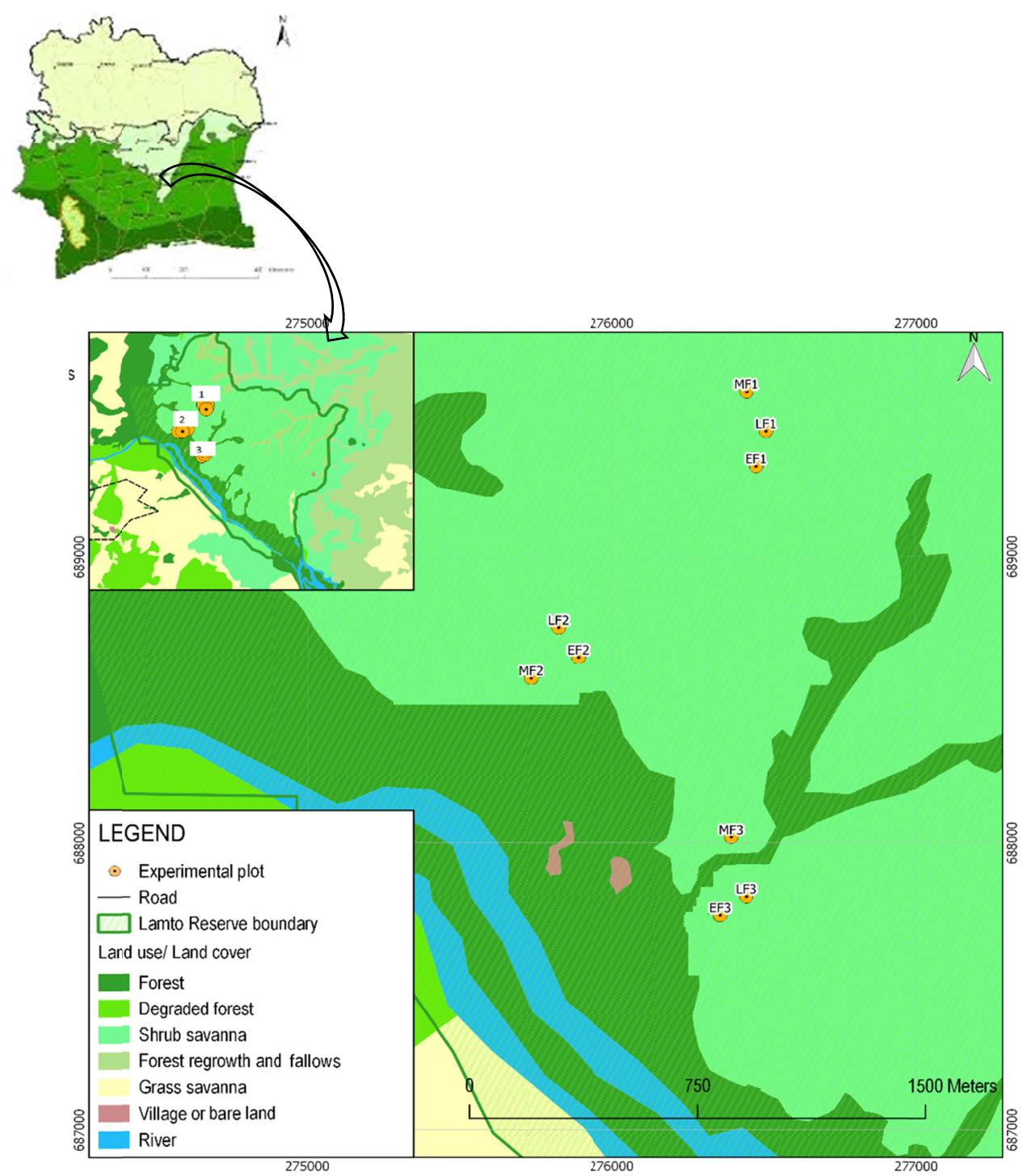

Figure 2. Location of the study site and distribution of plots in Lamto savanna. 1,2 and 3: experimental blocks. MF, LF and EF: mid-season fire, late season fire and early fire plots 
$230 \mathrm{~m}$
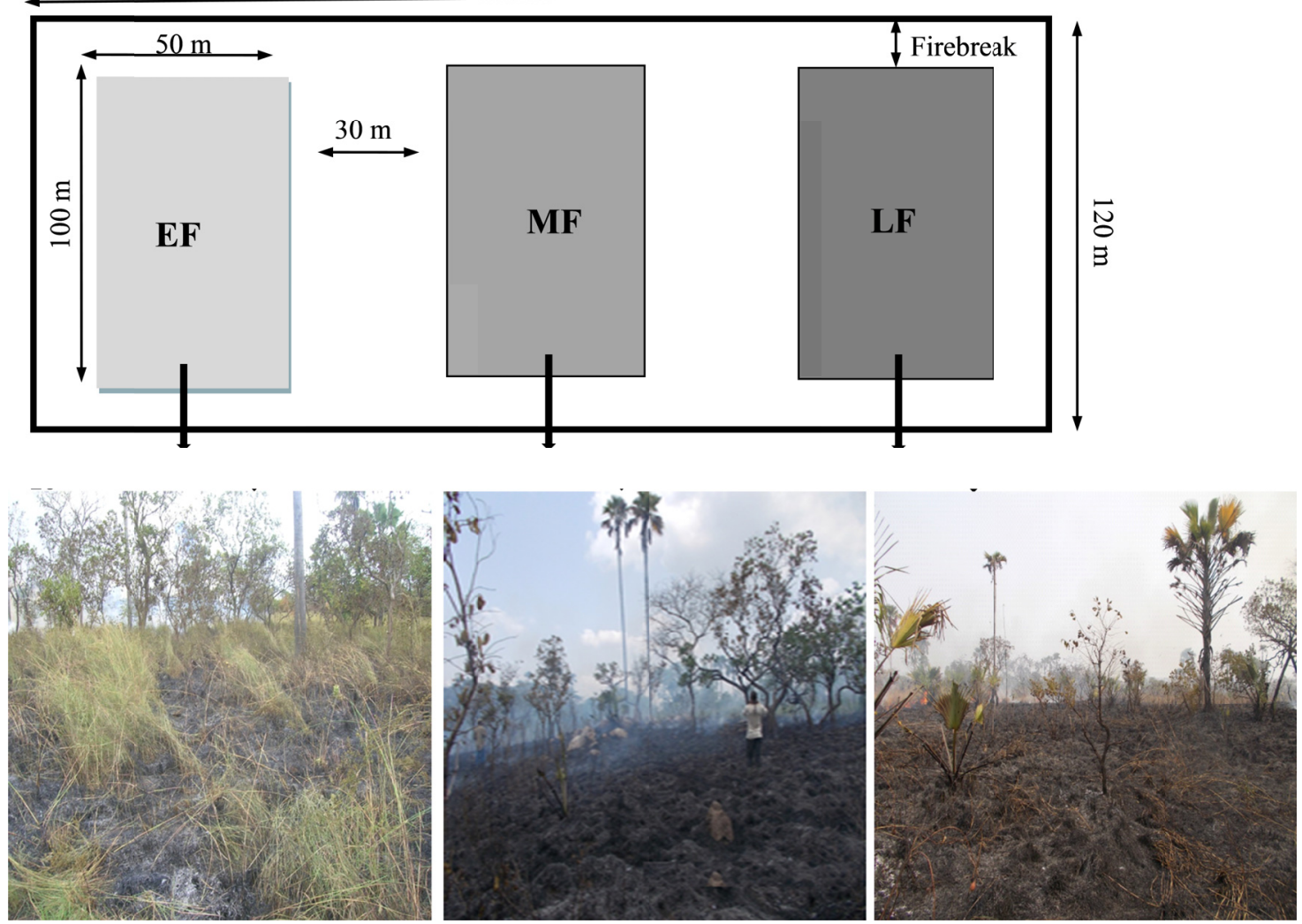

Figure 3. Experimental set up and plots after each fire. EF: Early Fire; MF: Mid-season Fire; LF: Late Fire

\subsection{Plant Biomass Measurement, Plot Burning and Ash Quantity Determination}

Prior to each fire, aboveground biomass was collected on ten $1 \mathrm{~m}^{2}$-quadrats per plot shortly (minutes) before burning to estimate fuel load. The biomass was separated into litter (fallen dead grass and tree leaves) and standing fuel (standing grass and stems), and immediately weighed for fresh mass (g). Samples were oven-dried at $80^{\circ} \mathrm{C}$ until constant weight and weighed for dry mass. Moisture content was then calculated. Immediately after each experimental fire, the remaining aboveground biomass was sampled in each plot from ten random quadrats of $1 \mathrm{~m}^{2}$, dried and, weighed, using techniques that are similar to the pre-fire samples. For each of the plant parts (stem, green leaves, dead leaves), samples from the ten quadrats were thoroughly mixed to obtain a composite sample for chemical analyses. Grass cover height $(\mathrm{m})$ was determined as the average vertical distance from the ground to the tip of the shoot of 50 randomly selected points.

The quantity of ash was determined using the technique of Mackensen et al. (1996). Prior to setting fires, ten steel trays $(50 \mathrm{~cm}$ x $50 \mathrm{~cm})$ were placed on the soil surface under grasses at ten points well distributed within each plot. Fires were ignited in the direction of the wind so as to prevent deposition of particulates between different plots. Ash samples were collected within $30 \mathrm{~min}$ after each fire to counter potential drift due to wind, weight and air dried. Bulked samples from each plot were then separated by sieving into $<1 \mathrm{~mm}, 1-2 \mathrm{~mm}$, and $>$ $2 \mathrm{~mm}$ fractions, referred to as fine, medium and coarse ash respectively. A composite aliquot from each plot was stored in plastic bags for laboratory chemical analyses.

\subsection{Laboratory Analyses: Plant and Ash Materials}

Organic carbon (OC) was determined using the Anne method (Nelson \& Sommers, 1982) which is a modified Walkley-Black (WB) method: samples were heated during oxidization, allowing for complete recovery of OC and no need to apply a correction factor as done in the WB method. Total nitrogen was determined by the Kjeldahl method (Anderson \& Ingram, 1993). Available phosphorus was extracted as per the Olsen-Dabin method (in a mixture of $\mathrm{NaHCO}_{3}$ and $\mathrm{NH}_{4} \mathrm{~F}$, at $\mathrm{pH} 8.5$ ), and then assayed by colorimetry at 660 nm (Murphy \& Riley, 1962). Major cations were extracted using a standard ammonium acetate ( $\mathrm{pH} 7$ ) buffer and measured by atomic absorption spectrometry (Anderson \& Ingram, 1993). 


\subsection{Calculations of Carbon and Nutrient Loss and $\mathrm{CO}_{2}$ Emission Due to Burning}

Loss of carbon $(\mathrm{C})$ and five elements $(\mathrm{N}, \mathrm{P}, \mathrm{K}, \mathrm{Ca}$, and $\mathrm{Mg}$ ) during burning were calculated by subtraction: the measured values in plant biomass prior to burning minus the values in ashes after burning and in unburnt biomass (Rossiter-Rachor et al., 2008). As described above, sampled vegetation did not include the few woody species on the sites.

Carbon and nutrient stocks in slashed biomass and in ashes and losses of those elements were calculated as:

$$
\begin{gathered}
\mathrm{ES}=(\mathrm{PM} \times \mathrm{EC}) / 100 \\
\mathrm{EL}=\left[\left(\mathrm{ESB}_{\mathrm{BB}}-\left(\mathrm{EA}+\mathrm{EPM}_{\mathrm{AB}}\right) / \mathrm{ESB}_{\mathrm{BB}}\right] \times 100\right.
\end{gathered}
$$

where ES is element stock $\left(\mathrm{g} \mathrm{m}^{-2}\right)$, PM is plant material ( $\mathrm{kg}$ ha-1) which refers to either slashed biomass or ashes, $\mathrm{EC}$ is element concentration (\%), $\mathrm{EL}$ is element loss (\%), $\mathrm{ESB}_{\mathrm{BB}}$ is element stock in biomass before burning ( $\mathrm{kg}$ $\left.\mathrm{ha}^{-1}\right)$, EA is element stock in ashes $\left(\mathrm{kg} \mathrm{ha}^{-1}\right)$, and $\mathrm{ESB}_{\mathrm{AB}}$ is element stock in biomass after burning $\left(\mathrm{kg} \mathrm{ha}^{-1}\right)$.$$
\mathrm{CO}_{2} \text { emission was calculated as follows: } \mathrm{C} \text { loss }\left(\mathrm{g} \mathrm{m}^{-2}\right) * 3.67 \text { (IPCC, 2002) }
$$ \\ 2.6 Measurements of Fire and Weather Characteristics}

Fire was ignited with a dry palm leaf along the shorter side of each plot in the direction of the wind, to rapidly establish a fire-line and ensure linear ignition. All burns were conducted in the morning (10:00 - 11:00 am) on the same day, in order to ensure similarity of fuel moisture levels and weather conditions (e.g, due to wind, air humidity and temperature). We characterized fire behaviour using six variables: rate of spread $\left(\mathrm{m} \mathrm{s}^{-1}\right)$, fire intensity $\left(\mathrm{kW} \mathrm{m}^{-1}\right)$, fire maximal temperature $\left({ }^{\circ} \mathrm{C}\right)$, residence time above $60^{\circ} \mathrm{C}(\mathrm{s})$, flame height $(\mathrm{m})$, and combustion efficiency (\%).

The rate of spread was determined by recording the time it took for a flame line to reach poles positioned every $10 \mathrm{~m}$ on both sides of each plot using stop watches.

Fire intensity was estimated using Byram's (1959) equation:

$$
\mathrm{I}\left(\mathrm{kW} \mathrm{m}^{-1}\right)=\mathrm{W} \mathrm{H} \mathrm{R}
$$

where: $W\left(\mathrm{~g} \mathrm{~m}^{-2}\right)$ is the mass of fresh fuel consumed; $H$ is the heat yield of the fuel, which for grass fuel 16,890 $\mathrm{kJ} \mathrm{kg}^{-1}$ is the recommended value (Trollope, 1983); and $R\left(\mathrm{~m} \mathrm{~s}^{-1}\right)$ is the rate of spread.

The fire residence time was defined as the time during which air temperature at ground level, measured with a thermocouple, was above $60^{\circ} \mathrm{C}$ - the commonly accepted lethal temperature for most plant cells (Daniell et al., 1969). We used self-built synchronized fire temperature recorders (SFTRs) to measure this time. Each SFTR was comprised of a thermocouple (type $\mathrm{K} 250 \mathrm{~mm}$ steel probe, 0 to $1100^{\circ} \mathrm{C}$ range) connected to a Raspberry Pi nano-computer (https://www.raspberrypi.org/), plus batteries. Prior to setting fires, the SFTRs were synchronized by sending a 'start' signal prior to burying them in the plots, with only the top $10 \mathrm{~cm}$ of the thermocouple probe protruding from the ground. They were placed at the ends of equilateral triangles, with sides $20 \mathrm{~m}$ in length. After the fires, the time series of temperatures were downloaded from the STFRs and residence times were computed from those data.

Flame height $(\mathrm{m})$ was measured on each plot and after each fire using 10 iron poles, each of $4 \mathrm{~m}$ height, on which $5 \mathrm{~cm}$-long pieces of sticking paper tape had been placed every $20 \mathrm{~cm}$. The flame height was equal to the maximal height where the paper was burnt. The 10 poles on each plot were distributed randomly; and heights were averaged over the ten poles for each plot (N'Dri et al., 2018a; b).

Immediately after each experimental fire, the residual unburned fuel in each plot from 10 random quadrats of 1 $\mathrm{m}^{2}$ was sampled, dried, and weighed, using techniques that were similar to those for the pre-fire samples. For each plot and fire, we used the average values of post-fire mass and the pre-fire mass to estimate combustion efficiency (\%).

During each fire, wind speed $\left(\mathrm{m} \mathrm{s}^{-1}\right)$, air temperature $\left({ }^{\circ} \mathrm{C}\right)$ and relative humidity $(\%)$ were recorded every five minutes, similar to methods of Kidnie and Wotton (2015), using an in situ automatic weather station (Model Pro, Ref.:SM55PRO) placed at $2 \mathrm{~m}$ above ground, in the fire break between two adjacent plots. The recorded values were averaged over the period of fire propagation for each plot.

\subsection{Statistical Analyses}

All statistical analyses were performed using the R software (R Development Core Team, 2014). ANOVA were performed to analyse: (i) the quantity of initial biomass, residual unburnt biomass, and total ash according to fire season, (ii) the carbon and nutrients losses to the fire season, (iii) fuel, fire behaviour, and weather characteristics 
according to the date of burning. Tukey multiple comparison tests (HSD) were used to compare the different modalities of significant effects. We used generalised linear models (GLMs) with Poisson error distributions to analyse the proportions of different ash fractions according to the date of burning. Correlation analyses were also performed to examine the relationship between on the one hand, total and different fractions of ash quantity, carbon and nutrients losses and on the other hand, fuel, fire and weather characteristics. Results were considered as significant when $\mathrm{p}<0.05$.

\section{Results}

\subsection{Fuel and Ash Load According to Fire Seasons}

Fresh fuel load before burning, residual unburnt fuel, and total ash load were higher during early fire than mid-season and late fires. There was no difference between mid and late season fires (Figure 4).

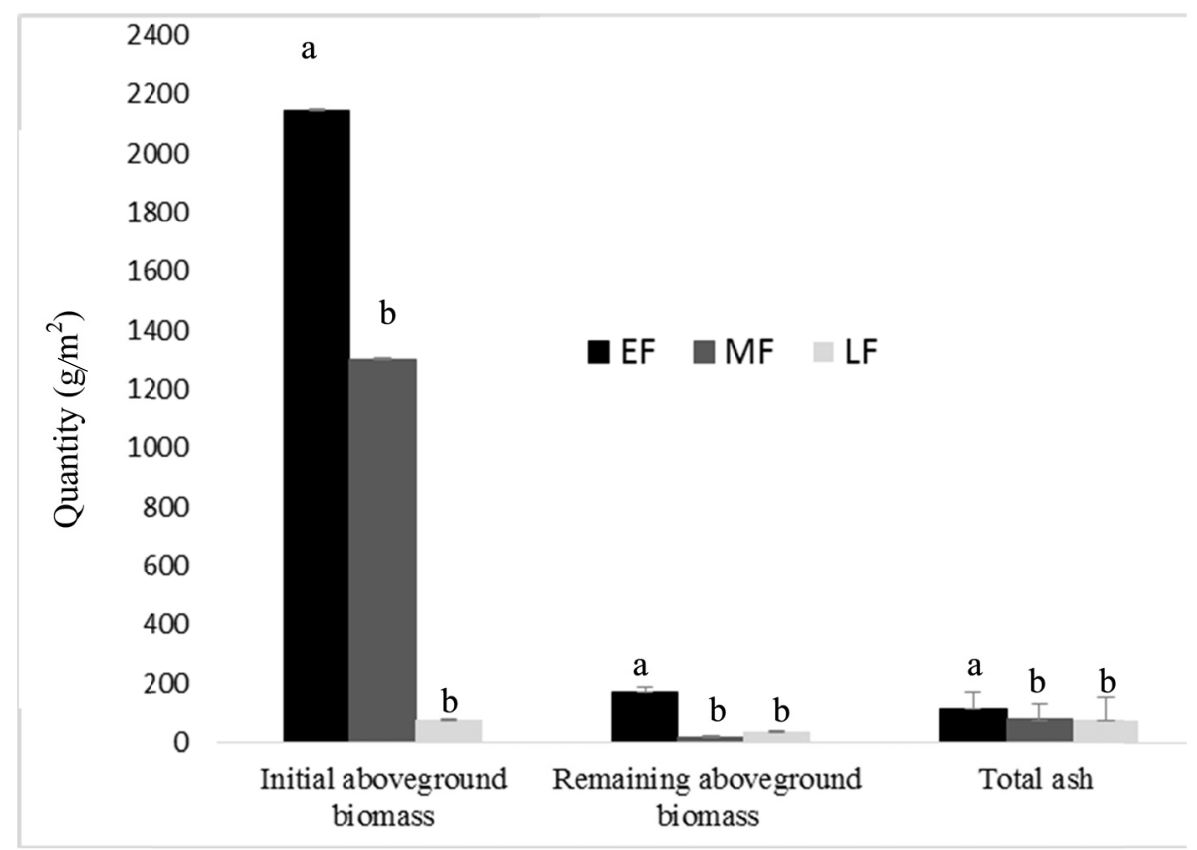

Figure 4. Quantity of initial aboveground biomass and remaining aboveground biomass and total ash according to burning date - Letters indicate groups of non-significantly different values between burning season (TukeyHSD post-hoc tests, $\alpha=0.05$ ). EF: Early fire; MF: Mid-season fire; LF: Late fire

\subsection{Ash Fractions}

During the early fire, the proportion and quantity of the fine ash fraction was the greatest and the coarse ash fraction proportion the lowest, and there was no difference between the quantity of medium and coarse ash fractions. The quantity and proportion of the fine fraction were significantly higher for the mid-season and late fires than for the early fire, and there was no difference between medium and coarse fractions quantity and proportion (Figure 5). 


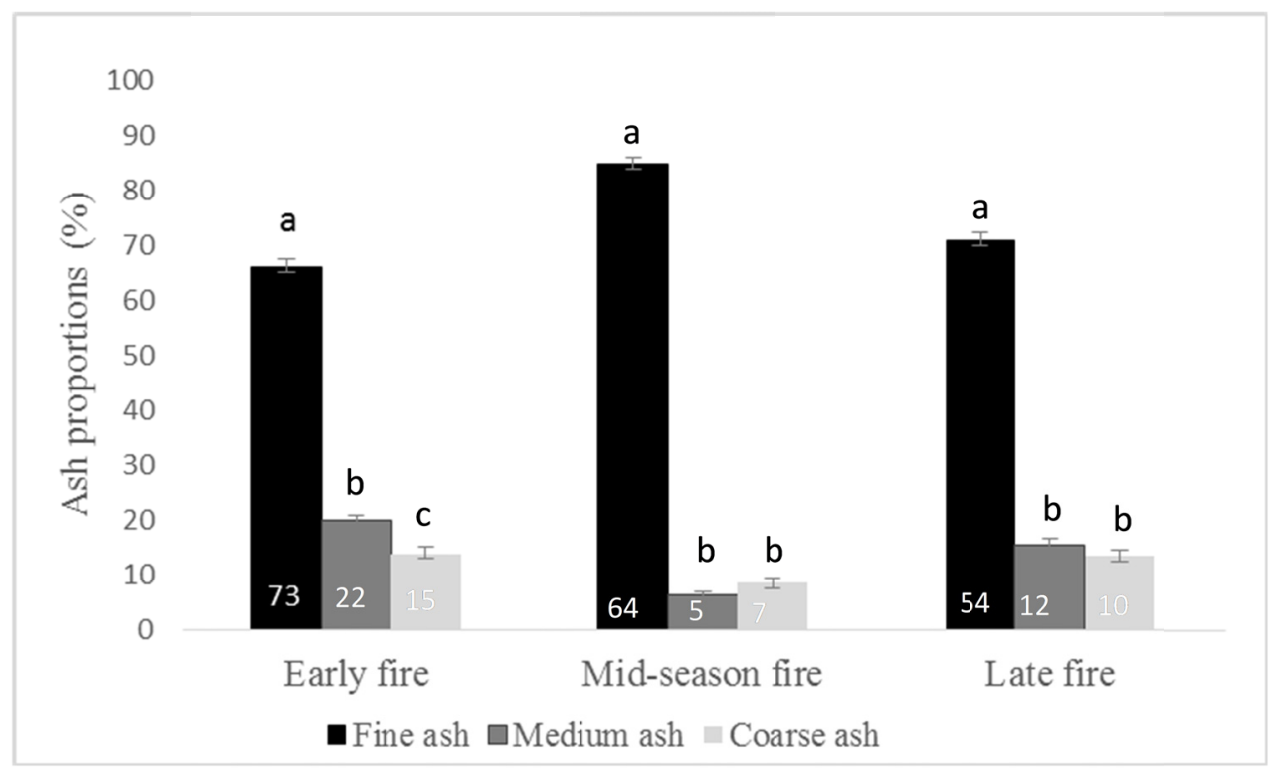

Figure 5. Proportion of ash fractions according to burning date - Letters indicate groups of non-significantly different values between burning dates (Tukey HSD post-hoc test, $\alpha=0.05$ ). Numbers on histogram bars represent the ash quantity in $\mathrm{g} \mathrm{m}^{-2}$

The proportion of ash fraction significantly differed between burning season (ANOVA, $\mathrm{F}_{2,87}=118.1, \mathrm{P}<0.0001$; $\mathrm{F}_{2,87}=102.4, \mathrm{P}<0.0001$; and $\mathrm{F}_{2,87}=18.44, \mathrm{P}<0.0001$, respectively for fine, medium, and coarse fractions). The fine ash fraction was the greatest for mid-season fire $(85 \pm 1 \%)$, followed by late fire $(71 \pm 1 \%)$ and was the lowest for early fire $(66 \pm 1 \%)$. The medium ash fraction was the greatest for early fire $(20 \pm 1 \%)$, followed by late fire $(15 \pm 1 \%)$, and the lowest for mid-season fire $(6 \pm 1 \%)$. The coarse ash fraction proportion was the lowest for mid-season fire $(9 \pm 1 \%)$ and did not vary between early $(14 \pm 1 \%)$ and late $(13 \pm 1 \%)$ fires.

\subsection{Concentrations of Carbon Nutrients in Ash Fractions According to Burning Date}

Concentrations of $\mathrm{C}$ and $\mathrm{N}$ were greater in the coarse ash fraction than in the fine fraction, irrespective of burning date. For all other nutrients, concentrations were greater in the fine ash fraction than in the coarse fraction. Concentrations of nutrients were generally the greatest during early fire, followed by that of mid-season fire and the lowest during late fire (Table 1).

Table 1. Carbon and nutrient contents in the different ash fractions (Mean \pm SE) according to burning date. All data in $\mathrm{g} \mathrm{m}^{-2}$

\begin{tabular}{|c|c|c|c|c|c|c|}
\hline Nutrients & $\mathrm{C}$ & $\mathrm{N}$ & $\mathrm{P}$ & $\mathrm{K}$ & $\mathrm{Ca}$ & $\mathrm{Mg}$ \\
\hline \multicolumn{7}{|l|}{ Early fire } \\
\hline Fine ash & $4.5 \pm 0.32$ & $0.14 \pm 0.01$ & $0.25 \pm 0.03$ & $1.11 \pm 0.09$ & $1.31 \pm 0.11$ & $0.65 \pm 0.02$ \\
\hline Medium ash & $5.6 \pm 0.94$ & $0.13 \pm 0.01$ & $0.10 \pm 0.01$ & $0.49 \pm 0.04$ & $0.45 \pm 0.03$ & $0.25 \pm 0.01$ \\
\hline Coarse ash & $10.9 \pm 2.71$ & $0.18 \pm 0.04$ & $0.04 \pm 0.01$ & $0.21 \pm 0.05$ & $0.20 \pm 0.05$ & $0.11 \pm 0.03$ \\
\hline \multicolumn{7}{|c|}{ Mid-season fire } \\
\hline Fine ash & $1.67 \pm 0.30$ & $0.04 \pm 0.003$ & $0.11 \pm 0.02$ & $0.44 \pm 0.07$ & $0.56 \pm 0.071$ & $0.30 \pm 0.04$ \\
\hline Medium ash & $0.82 \pm 0.10$ & $0.01 \pm 0.001$ & $0.02 \pm 0.003$ & $0.076 \pm 0.01$ & $0.06 \pm 0.002$ & $0.04 \pm 0.006$ \\
\hline Coarse ash & $4.80 \pm 0.62$ & $0.04 \pm 0.003$ & $0.03 \pm 0.003$ & $0.12 \pm 0.01$ & $0.06 \pm 0.006$ & $0.05 \pm 0.002$ \\
\hline \multicolumn{7}{|l|}{ Late fire } \\
\hline Fine ash & $1.40 \pm 0.1$ & $0.03 \pm 0.003$ & $0.06 \pm 0.0004$ & $0.21 \pm 0.013$ & $0.38 \pm 0.02$ & $0.16 \pm 0.006$ \\
\hline Medium ash & $1.01 \pm 0.16$ & $0.02 \pm 0.004$ & $0.010 \pm 0.0003$ & $0.04 \pm 0.002$ & $0.06 \pm 0.008$ & $0.03 \pm 0.003$ \\
\hline Coarse ash & $3.44 \pm 0.34$ & $0.05 \pm 0.009$ & $0.017 \pm 0.0018$ & $0.06 \pm 0.006$ & $0.09 \pm 0.02$ & $0.04 \pm 0.007$ \\
\hline
\end{tabular}




\subsection{The Total Transfer of Plant Carbon and Nutrients to the Atmosphere and $\mathrm{CO}_{2}$ Emission According To Burning Date}

The average biomass of understory plant species was $1340 \pm 113,890 \pm 87$, and $826 \pm 68 \mathrm{~g} \mathrm{~m}^{-2}$ respectively for early, mid-season and late fires, of which carbon represented $42 \%, 43 \%$ and $46 \%$ respectively (Table 2 ).

Except for nitrogen, losses of nutrients were lower for early fire than for the two other burning dates, and there was no significant difference between mid and late fires. More than $75 \%$ of phosphorus, potassium, calcium, and magnesium were lost during mid-season and late fires, while only about $50 \%$ was lost during early fire (Figure 6, Table 2). Carbon and nitrogen were almost completely lost. Carbon losses were greater during mid-season and late fires than during early fire.

$\mathrm{CO}_{2}$ emission did not vary according to burning date (Anova, $\mathrm{F}_{2,6}=1.303, \mathrm{p}=0.33$ ), the trend was the highest emission during early fire $\left(1623.41 \mathrm{~g} \mathrm{~m}^{-2}\right)$ than during the mid-season $\left(1367.01 \mathrm{~g} \mathrm{~m}^{-2}\right)$ and late $\left(1332.12 \mathrm{~g} \mathrm{~m}^{-2}\right)$ fires.

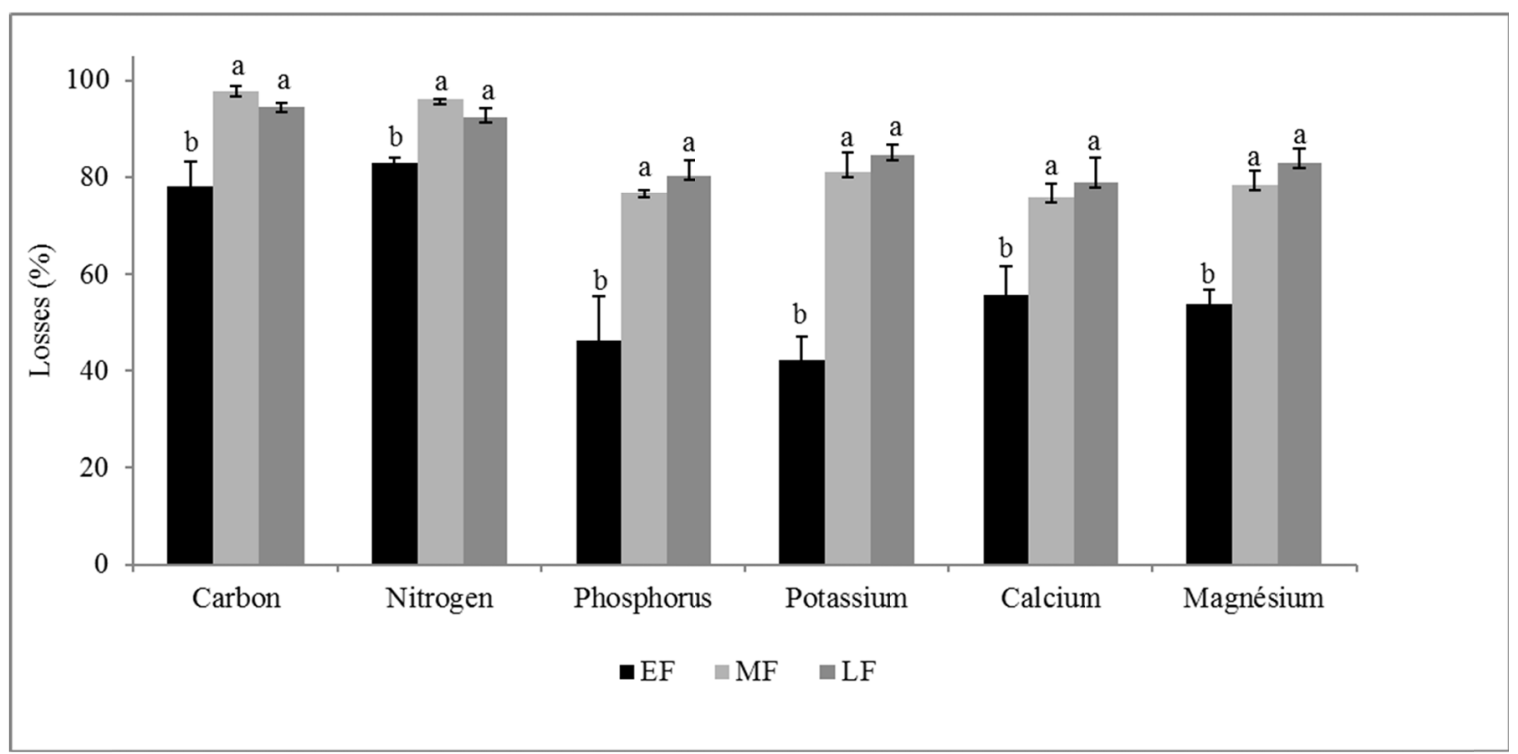

Figure 6. Carbon and nutrients released to the atmosphere according to burning date - EF: Early fire; MF: Mid-season fire, LF: Late fire. Letters indicate groups of non-significantly different values between burning dates (Tukey HSD post-hoc tests, $\alpha=0.05$ )

Table 2. Carbon and nutrients in the biomass before fire and in the remaining biomass after fire, in ash, and losses according to burning date. All data in $\mathrm{g} \mathrm{m}^{-2}$

\begin{tabular}{lllllll}
\hline Nutrients & $\mathrm{C}$ & $\mathrm{N}$ & $\mathrm{P}$ & $\mathrm{K}$ & $\mathrm{Ca}$ & $\mathrm{Mg}$ \\
\hline Early fire & & & & & & \\
Fuel before fire & $560.55 \pm 45.53$ & $6.49 \pm 0.45$ & $1.13 \pm 0.09$ & $5.83 \pm 0.42$ & $5.52 \pm 0.37$ & $3.03 \pm 0.13$ \\
Fuel after fire & $74.33 \pm 12.86$ & $0.66 \pm 0.18$ & $0.21 \pm 0.07$ & $1.57 \pm 0.43$ & $0.45 \pm 0.074$ & $0.37 \pm 0.07$ \\
Ash & $21.01 \pm 3.97$ & $0.44 \pm 0.06$ & $0,39 \pm 0.05$ & $1.81 \pm 0.17$ & $1.96 \pm 0.19$ & $1.02 \pm 0.06$ \\
Losses & $442.35 \pm 62.04$ & $5.39 \pm 0.32$ & $0.53 \pm 0.14$ & $2.44 \pm 0.33$ & $3.11 \pm 0.49$ & $1.63 \pm 0.16$ \\
Mid season fire & & & & & & \\
Fuel before fire & $381.42 \pm 13.49$ & $3.00 \pm 0.25$ & $0.78 \pm 0.08$ & $4.09 \pm 0.61$ & $2.98 \pm 0.24$ & $2.04 \pm 0.22$ \\
Fuel after fire & $6.39 \pm 3.39$ & $0.03 \pm 0.013$ & $0.01 \pm 0.006$ & $0.08 \pm 0.04$ & $0.02 \pm 0.011$ & $0.03 \pm 0.02$ \\
Ash & $7.30 \pm 1.02$ & $0.09 \pm 0.008$ & $0.17 \pm 0.02$ & $0.64 \pm 0.09$ & $0.68 \pm 0.08$ & $0.40 \pm 0.05$ \\
Losses & $372.48 \pm 9.19$ & $2.88 \pm 0.24$ & $0.60 \pm 0.06$ & $3.36 \pm 0.65$ & $2.27 \pm 0.28$ & $1.61 \pm 0.23$ \\
Late fire & & & & & & \\
Fuel before fire & $384.02 \pm 18.73$ & $4.34 \pm 0.53$ & $0.64 \pm 0.11$ & $2.96 \pm 0.18$ & $3.79 \pm 0.24$ & $1.89 \pm 0.13$ \\
Fuel after fire & $15.16 \pm 2.68$ & $0.20 \pm 0.05$ & $0.03 \pm 0.005$ & $0.14 \pm 0.03$ & $0.23 \pm 0.09$ & $0.09 \pm 0.02$ \\
Ash & $5.86 \pm 0.60$ & $0.10 \pm 0.016$ & $0.09 \pm 0.002$ & $0.31 \pm 0.015$ & $0.54 \pm 0.06$ & $0.23 \pm$ \\
Losses & $362.98 \pm 19.82$ & $4.03 \pm 0.56$ & $0.52 \pm 0.10$ & $2.51 \pm 0.18$ & $3.02 \pm 0.36$ & $1.57 \pm 0.14$ \\
\hline & & & & & & \\
\hline
\end{tabular}




\subsection{Fuel, Fire and Weather Parameters}

Grass height was the highest for the early dry season and the lowest for the late dry season. The standing biomass and the total fresh fuel load (standing biomass + litter before drying) were significantly higher for the early dry season than for the mid and late dry seasons. There was no significant difference between mid and late dry seasons. Litter moisture content was significantly lower for the mid dry season than for the early and late dry seasons. There was no significant difference in litter moisture content between early and late dry seasons. Fresh litter, standing fuel moisture content, and total fuel moisture content did not vary with burning date (Table 3 ).

The fire rate of spread was the highest in EF and the lowest in MF, while fire intensity was the highest in MF and the lowest in EF. LF presented intermediate values. The maximal temperature and flame height were significantly higher for the MF than for the EF and LF. There was no significant difference between EF and LF. The combustion efficiency was significantly lower for EF than for the MF and LF. There was no significant difference between MF and LF. Residence time above $60^{\circ} \mathrm{C}$ did not vary with burning date (Table 3 ).

The weather characteristics did not vary according to the burning date (Table 3).

Table 3. Response of biomass, fire behaviour, and weather characteristics to the burning date

\begin{tabular}{|c|c|c|c|}
\hline & Early fire & Mid-season fire & Late fire \\
\hline \multicolumn{4}{|c|}{ Fuel variables } \\
\hline GH & $2.10 \pm 0.07^{\mathrm{a}}$ & $1.80 \pm 0.02^{\mathrm{b}}$ & $1.42 \pm 0.08^{\mathrm{c}}$ \\
\hline BM & $1.90 \pm 0.16^{\mathrm{a}}$ & $1.08 \pm 0.11^{\mathbf{b}}$ & $1.28 \pm 0.09^{\mathrm{b}}$ \\
\hline $\mathbf{L M}$ & $0.25 \pm 0.02^{\mathrm{a}}$ & $0.22 \pm 0.01^{\mathrm{a}}$ & $0.20 \pm 0.01^{\mathrm{a}}$ \\
\hline BC & $43.11 \pm 0.95^{\mathrm{a}}$ & $34.93 \pm 5.77^{\mathrm{a}}$ & $43.73 \pm 0.52^{\mathrm{a}}$ \\
\hline LC & $17.51 \pm 2.05^{\mathrm{a}}$ & $4.06 \pm 1.41^{\mathrm{b}}$ & $14.50 \pm 2.87^{\mathrm{a}}$ \\
\hline TFC & $40.02 \pm 0.66^{\mathbf{a}}$ & $31.22 \pm 6.47^{\mathrm{a}}$ & $39.44 \pm 0.22^{\mathrm{a}}$ \\
\hline \multicolumn{4}{|c|}{ Fire behaviour parameters } \\
\hline RoS & $0.19 \pm 0.61^{\mathrm{a}}$ & $0.02 \pm 0.01^{\mathrm{b}}$ & $0.05 \pm 0.01^{\mathrm{ab}}$ \\
\hline FI & $714.41 \pm 14.54^{\mathrm{b}}$ & $3943.02 \pm 1062.85^{\mathrm{a}}$ & $1274.64 \pm 49.35^{\mathrm{ab}}$ \\
\hline RT $>60^{\circ} \mathrm{C}$ & $2.46 \pm 0.02^{\mathrm{a}}$ & $2.18 \pm 0.05^{\mathrm{a}}$ & $2.43 \pm 0.18^{\mathrm{a}}$ \\
\hline Max. $\mathbf{T}^{\circ}$ & $472.56 \pm 12.10^{b}$ & $604.06 \pm 7.16^{\mathrm{a}}$ & $519.90 \pm 20.46^{\mathbf{b}}$ \\
\hline FH & $1.31 \pm 0.19^{\mathbf{b}}$ & $2.65 \pm 0.18^{\mathrm{a}}$ & $1.92 \pm 0.02^{\mathrm{b}}$ \\
\hline $\mathbf{C E}$ & $91.93 \pm 1.88^{\mathbf{b}}$ & $98.96 \pm 0.54^{\mathbf{a}}$ & $97.47 \pm 0.66^{\mathbf{a}}$ \\
\hline \multicolumn{4}{|c|}{ Weather conditions } \\
\hline AT & $33.45 \pm 2.36^{\mathbf{a}}$ & $32.8 \pm 2.40^{\mathrm{a}}$ & $32.7 \pm 1.96^{\mathrm{a}}$ \\
\hline $\mathbf{A H}$ & $62.97 \pm 9.47^{\mathrm{a}}$ & $45.7 \pm 9.01^{\mathrm{a}}$ & $55.65 \pm 1.93^{\mathrm{a}}$ \\
\hline WS & $1.63 \pm 1.34^{\mathrm{a}}$ & $3.8 \pm 1.89^{\mathrm{a}}$ & $5.4 \pm 1.44^{\mathrm{a}}$ \\
\hline
\end{tabular}

GH: Grassy understory height $(\mathrm{m})$; BM: Biomass $\left(\mathrm{kg} \mathrm{m}^{-2}\right)$; LM: Litter mass $\left(\mathrm{kg} \mathrm{m}^{-2}\right)$; BC: Biomass moisture content (\%); LC: Litter moisture content (\%); TFC: Total fuel moisture content (\%); RoS: Fire Rate of spread (m $\left.\mathrm{s}^{-1}\right)$; FI: Fire intensity $\left(\mathrm{kW} \mathrm{m}^{-1}\right)$; RT $>60^{\circ} \mathrm{C}$ : Fire Residence time above $60^{\circ} \mathrm{C}(\mathrm{s})$; Max. $\mathbf{T}^{\circ}$ : Fire Maximal temperature $\left({ }^{\circ} \mathrm{C}\right)$; $\mathbf{F H}$ : Flame height (m); CE: Combustion efficiency $(\%)$; AT: Air temperature $\left({ }^{\circ} \mathrm{C}\right)$; $\mathbf{A H}$ : Air humidity (\%), WS: Wind speed $\left(\mathrm{m} \mathrm{s}^{-1}\right)$. Letters indicate groups of non-significantly different values between burning dates (Tukey HSD post-hoc tests, $\alpha=0.05$ ).

\subsection{Effects of Fuel, Fire and Climate Characteristics on the Proportion of Nutrient Losses}

Standing fuel moisture content, Total fuel moisture content, Residence time above $60^{\circ} \mathrm{C}$, air temperature, relative humidity, and wind speed which did not show any correlation with ash characteristics and carbon and nutrients losses, were remove from table 4. Among fuel characteristics, the total fuel and live fuel moisture contents neither explained ash quantity nor nutrients losses. Medium and coarse ash fractions were negatively influenced by the fire rate of spread and intensity, and the maximal fire temperature. The live fuel and total fuel loads, and litter moisture content influenced positively these ash fractions.

$\mathrm{C}, \mathrm{N}$ and $\mathrm{K}$ losses were negatively correlated with standing fuel and total fresh fuel loads, but positively correlated with the maximal fire temperature and flame height. The maximal fire temperature was also positively correlated with $\mathrm{Ca}$ and $\mathrm{Mg}$ losses. No climate characteristic explained ash quantity and nutrient losses (Table 4). 
Table 4. Correlation coefficients for the relationships involved.

\begin{tabular}{|c|c|c|c|c|c|c|c|c|c|c|}
\hline & $\mathrm{GH}$ & $\mathrm{BM}$ & LM & TFL & LC & RoS & FI & Max. $T^{\circ}$ & $\mathrm{FH}$ & $\mathrm{CE}$ \\
\hline Ash quantity & 0.77 & 0.86 & NS & 0.88 & NS & NS & NS & NS & NS & NS \\
\hline Fine ash & 0.84 & NS & NS & NS & NS & NS & NS & NS & NS & NS \\
\hline Medium ash & NS & 0.95 & NS & 0.94 & 0.86 & -0.71 & -0.71 & -0.81 & -0.8 & -0.67 \\
\hline Coarse ash & NS & 0.85 & NS & 0.86 & 0.75 & -0.8 & -0.79 & -0.84 & -0.8 & -0.77 \\
\hline C loss & NS & -0.68 & NS & -0.71 & NS & NS & NS & 0.74 & 0.88 & 0.99 \\
\hline $\mathrm{N}$ loss & NS & -0.72 & NS & -0.74 & NS & NS & NS & 0.87 & 0.86 & 0.94 \\
\hline $\mathrm{K}$ loss & NS & -0.7 & NS & -0.74 & NS & NS & NS & 0.68 & 0.74 & 0.90 \\
\hline P loss & 0.68 & NS & NS & NS & NS & NS & NS & NS & NS & NS \\
\hline Ca loss & NS & NS & -0.88 & NS & NS & NS & NS & 0.67 & NS & 0.87 \\
\hline Mg loss & NS & -0.72 & -0.8 & -0.75 & NS & NS & NS & 0.68 & NS & 0.84 \\
\hline
\end{tabular}

GH: Grassy understory height (m); BM: Biomass $\left(\mathrm{kg} \mathrm{m}^{-2}\right)$; LM: Litter load $\left(\mathrm{kg} \mathrm{m}^{-2}\right)$; TFL: Total fuel loads $(\mathrm{kg}$ $\left.\mathrm{m}^{-2}\right)$; LC: Litter moisture content (\%); RoS: Fire Rate of spread $\left(\mathrm{m} \mathrm{s}^{-1}\right)$; FI: Fire intensity $\left(\mathrm{kW} \mathrm{m}^{-1}\right)$; Max. $\mathbf{T}^{\circ}$ : Fire Maximal temperature $\left({ }^{\circ} \mathrm{C}\right)$; FH: Flame height (m); CE: Combustion efficiency; NS: non-significant.

\section{Discussion}

\subsection{Ash Fractions Related to Different Burning Dates}

The higher proportion of fine ash than coarse ash irrespective of the burning date could be explained by a good combustion efficiency measured in our experimental plots (over $90 \%$ for the three fire seasons). Raison et al. (1985b) and Bodí et al. (2014) suggested that the proportion of fine ash increases with combustion completeness. Accordingly, the greater proportion of fine ash fraction recorded in the MF, could be attributed to its better combustion efficiency. In addition, the greater proportion of fine ash and lower proportion of coarse ash for MF, could be explained by its lower biomass, and its relatively highest values of fire rate of spread, intensity, combustion efficiency, flame height and fire maximal temperature. Indeed, our correlation matrix showed a positive correlation between coarse ash fraction and biomass, and the negative correlation between the coarse ash fraction and these fire behaviour parameters.

Indirect losses of particulate matter resulting from wind may affect more the fine ash fraction than the others (Raison et al., 1985b, Bodí et al., 2014). Since the proportion of the fine fraction was the greatest for MF, the indirect nutrient losses could potentially be the highest under this fire regime. These indirect losses concern mainly the less volatile ( $\mathrm{K}$ and $\mathrm{P})$ and nonvolatile $(\mathrm{Ca})$ elements.

\subsection{Losses of Carbon and Nutrients From Biomass During Fires}

As commonly reported (Raison et al., 1985a, 1985b; Cook, 1994; Rossiter-Rachor et al., 2008, and references therein), an important fraction of carbon and nutrients contained in grass biomass was released into the atmosphere during fire in the present study. The lower the temperature of vaporization of a chemical element, the higher its rate of volatilization (Mackensen et al., 1996). Based on this, our investigated nutrients may be ranked as follows, from lower to higher temperature of volatilization: $\mathrm{N}>\mathrm{P}>\mathrm{K}>\mathrm{Mg}>\mathrm{Ca}$ (Mackensen et al., 1996). This ranking was only found for MF. For the other burning dates, the following rankings were found: $\mathrm{C}>\mathrm{N}>\mathrm{K}>$ $\mathrm{Mg}>\mathrm{P}>\mathrm{Ca}$ for $\mathrm{LF}$ and, $\mathrm{N}>\mathrm{C}>\mathrm{Ca}>\mathrm{Mg}>\mathrm{P}>\mathrm{K}$ for EF. Both display a striking deviation regarding $\mathrm{P}$ and $\mathrm{K}$.

The fact that nitrogen and carbon had the highest $(>75 \%)$ losses is perhaps not surprising as they both have relatively lower temperatures of volatilization, from $200{ }^{\circ} \mathrm{C}$ to $350{ }^{\circ} \mathrm{C}$ (Fernández et al., 1997). The mean maximal temperature during our experimental fires were over $450{ }^{\circ} \mathrm{C}$ for the different fire seasons, possibly explaining these important losses of $\mathrm{C}$ and $\mathrm{N}$. Calcium has a temperature of volatilization of $1484^{\circ} \mathrm{C}$ that is far higher than the temperature of volatilization of the other elements. Accordingly, it was lost the least during the EF (with the lowest temperatures). There is no clear reason for the higher than expected level of Ca loss during all fire regimes. Phosphorus and potassium have intermediate temperatures of volatilization, between $774{ }^{\circ} \mathrm{C}$ and $800{ }^{\circ} \mathrm{C}$, explaining their intermediate rates of loss during $\mathrm{EF}$ and $\mathrm{MF}$ as compared to $\mathrm{C}$ and N. Surprisingly, they were lost me most during EF. It is possible that our method used to estimate losses could have over-estimated loss, particularly for $\mathrm{P}, \mathrm{Mg}$ and $\mathrm{Ca}$, because ash collection trays were retrieved about $30 \mathrm{~min}$ after fires, and the finest ash fraction probably was still in the air and was not taken into account. Had we waited for a longer time before retrieving trays, ash drift due to even the very mild winds of the day could have distorted values even further. Overall, we consider the portion of any fine ash that might not have settled 30 minutes after fires as insignificant, relative to the much larger volumes of the ash samples. 
The generally lower losses of carbon and nutrient during EF than MF and LF recorded in our study could be explained by the greener biomass and its higher moisture at that date, which prevent complete burning (Figure 2), leading to relatively lower fire intensity, temperature, and combustion efficiency (Table 3). Accordingly, C, N, and $\mathrm{K}$ losses were positively correlated with combustion efficiency and maximal temperature during fire (Table 4).

The rates of nutrient loss we measured were close to values reported by N'Dri et al. (2018c) in fallow systems around Lamto reserve. Whereas, the rates of nutrient loss measured by Villecourt et al. (1980) in Lamto over two years during mid-season fire $(\mathrm{C}, 97 \%$; N, 90\%; P, 13\%; K, 44\%; Ca, 27\%) were generally lower than those we measured. In addition, these authors might have overestimated the losses because they did not take into account the residual unburnt fuel in their calculation. The higher losses we obtained could be explained by the fire intensity that has likely increased in Lamto, due to higher rainfalls and the subsequent higher grass biomass. The mean fire intensity measured from 2009 to 2010 was $2966 \mathrm{~kW} \mathrm{~m}^{-1}$ and $1673 \mathrm{~kW} \mathrm{~m}^{-1}$ for MF and LF, respectively (N'Dri et al. 2012), whereas that measured from 2013 to 2017 were $3920 \mathrm{~kW} \mathrm{~m}^{-1}$, and $3134 \mathrm{~kW} \mathrm{~m}^{-1}$ for MF and LF, respectively (N'Dri et al., 2018a). Losses measured by Laclau et al. (2002) using Villecourt et al.' (1980) method, in the littoral savanna of Congo (N 85\%, P 25\%, K 39\%, Ca 21\%, and Mg 28\%), were also lower than ours, probably due to the lower biomass in Congo savanna.

Losses of $\mathrm{C}$ and $\mathrm{N}$ nearly reached $100 \%$ irrespective of the burning date. The $\mathrm{N}$ stocks in aboveground biomass $\left(6,3\right.$ and $4 \mathrm{~g} \mathrm{~m}^{-2}$, respectively for $\mathrm{EF}, \mathrm{MF}$ and $\left.\mathrm{LF}\right)$ were almost completely lost $\left(-5,-3\right.$ and $-4 \mathrm{~g} \mathrm{~m}^{-2}$ respectively) mainly through gaseous forms. Thus, burning plays an important role in the losses of nutrients.

\subsection{Implications for Savanna Functioning and Land Management}

The recurring losses of nutrients caused by annual fires may be causing irreversible nutrient rundown of the Lamto savanna. Our study showed that the MF fire implemented since 1962 in that savanna causes higher losses.

The approximate annual $\mathrm{N}$ inputs to Lamto savanna from natural sources are $29 \mathrm{~kg} \mathrm{ha}^{-1}$ year $^{-1}$, including $19 \mathrm{~kg}$ of wet deposition and about $10 \mathrm{~kg}$ from non-symbiotic biological fixation (Villecourt et al., 1980). The annual N outputs were also estimated to $15.6 \mathrm{~kg} \mathrm{ha}^{-1}$ year $^{-1}$, including $10 \mathrm{~kg}$ from fire, and 5.6 from drainage (Villecourt et al., 1980). Therefore, Abbadie (2006) concluded that $\mathrm{N}$ fixation was sufficient to replace annual losses due to mid-season fire. However, the loss of $\mathrm{N}$ from fire only in our study was $29 \mathrm{~kg} \mathrm{ha}^{-1} \mathrm{year}^{-1}$ for mid-season fire, the main fire regime in Lamto which is three time as high as the value reported by Abbadie et al. (2006). Fire intensity becoming higher, losses also becoming greater, which could lead to the low equilibrium between inputs and outputs of $\mathrm{N}$. Moreover, the processes by which $\mathrm{N}$ is stored in soil organic matter or in microbial biomass and released through mineralization may be strongly affected by fire (Menaut et al., 1993). The substantial losses of $\mathrm{N}$ caused by burning are potentially reversible if fire is excluded for several years, but this is unlikely to occur, as fire is the main tool to maintain savanna in this area where forests can also grow (Devineau et al., 1984). Therefore, fire can cause considerable losses of all nutrients to the atmosphere, but nitrogen being one of the main component of phytomass, its losses is much greater than those of other nutrients, as we recorded in our study, and in studies of Cook (1994), and Kauffman et al. (1995). As a result, repeated fires are likely to promote a shortage of N, and many savannas are thought to be primarily N-limited in soil and primary production (Abbadie, 2006). This could explain the almost zero nitrogen content of soils observed in Lamto (Riou, 1974).

Atmospheric inputs of P are only about $3.6 \mathrm{~kg} \mathrm{ha}^{-1}$ year $^{-1}$ (Villecourt et al., 1980) and are clearly insufficient to balance outputs we recorded (6 $\mathrm{kg}$ for MF and about $5 \mathrm{~kg}$ for $\mathrm{EF}$ and $\mathrm{LF}$ ). Transfer of $\mathrm{K}, \mathrm{Ca}$, and $\mathrm{Mg}$ to the atmosphere in repeated fires is likely to have less impact on short-term savanna nutrition than losses of $\mathrm{N}$ and $\mathrm{P}$ that are more widely deficient elements for tree growth in the Lamto savanna (Riou, 1974; Koné et al., 2008). Cech (2008), also found that biomass production was co-limited by $\mathrm{N}$ and $\mathrm{P}$ in frequently burnt humid savannas of Tanzania. Humid savannas are often limited by shortages of N, P, or both (Högberg, 1986; Medina, 1987; Ludwig et al. 2004).

The losses of $\mathrm{C}$ and nutrients are well known for mid-season fire in Lamto (Villecourt et al. 1980; Abbadie, 2006), but no information is available for early and late fire. But according to Coutinho (1990), the seasonal variations of $\mathrm{C}$ and nutrients in plants suggest an intensive and efficient adsorption of the ash nutrients that return to the soil after burnings. However, because rains tend to be more frequent when late fires occur, ash nutrients could be quickly incorporated into the soil, whereas a great part of ash nutrients could be lost by wind after mid-season fire. The important losses of $\mathrm{C}$ seem to threaten the life of this ecosystem by reducing its source of energy.

Moreover, biomass burning contributes to the increase in the atmospheric budget of several gases, mainly carbon dioxide (Crutzen \& Andreae 1990). Our study showed that $\mathrm{EF}$ seem to contribute to the increase of $\mathrm{CO}_{2}$ in 
atmosphere than MF and LF, contrary to Koné (2012) who suggested that less intense burning also produces less gas emissions into the atmosphere.

The choice of the fire management strategy to control bush encroachment in Lamto must consider fire impact on the carbon and nutrients dynamics. Fire regime should be selected to reduce losses of nutrients on the long term. The data collected, when combined with other information on the effects of fire and estimates of natural rates of element replacement, can be used to guide managers in the selection of appropriate fire regimes.

\section{Conclusion}

This study is one of the first focusing on carbon and nutrient losses during biomass burning at different burning dates. Significant quantity of all nutrients was transferred to the atmosphere during fires in Lamto savanna, but N losses were the highest during the mid-season fire, and likely to greatly exceed the inputs based on the currently available data. The losses of $\mathrm{N}$ were highly correlated to flame height and fire maximal temperature, which were the highest during MF.

This work indicates that, under an annual burning in which the burns are complete as MF, the nitrogen reserves of savanna may be depleted. To reduce the likelihood of this occurring, others burning seasons have to explored, helping land managers to develop management options to reduce nutrient losses from fires. Carbon and nutrients losses from wind and rainfall may increase the output and must be estimated during further studies.

\section{Acknowledgements}

This work was supported by the ASCAD (Académie des Sciences, des Arts des Cultures d'Afrique et des Diasporas Africaines) postdoctoral fellowship, the Programme d'Appui Stratégique à la Recherche Scientifique (PASRES Project $\mathrm{N}^{\circ}$ 105), and IRD (Institut de Recherche pour le Développement) through the JEAI (Jeune Equipe Assoicée) programme. We thank Emma Rochelle-Newall for their financial contribution for laboratory analysing. We thank the director of Lamto Geophysical Station, Prof. Diawara Adama for access to climate data, and Yéo Kolo the director of the Lamto Research Station for field access and logistics. We also thank Honoré Kounan and the entire team, including the numerous students, of our project called 'GIDES (Gestion Intégrée et Durable des Ecosystèmes de Savane)' for their help during the field work. The assistance of Gignoux. J and Barot. $\mathrm{S}$ in improving earlier drafts of this paper is much appreciated.

\section{References}

Abbadie, L., (2006). Nitrogen inputs to and outputs from the soil-plant system. In L. Abbadie, J. Gignoux, X. Le Roux, \& M. Lepage (Eds.), Lamto: Structure, Functioning, and Dynamics of a Savanna Ecosystem (pp. 255275). Springer, New York.

Abbadie, L., Gignoux, G., Lepage, M., \& Le Roux, X. (2006). Environmental constraints on living organisms. In L. Abbadie, J. Gignoux, X. Le Roux, \& M. Lepage (Eds.), Lamto: Structure, functioning and dynamics of a savanna ecosystem (pp. 45-61). Verlag, New-York: Springer.

Anderson, J. M., \& Ingram, J. S. I. (1993). Tropical soil biology and fertility: a handbook of methods (2nd ed.). New York: CAB international.

Andreae., M. O. (1991). Biomass burning: Its history, use, and distribution and its impact on environmental quality and global climate. In J. S. Levine (Ed.), Global Biomass Burning (pp. 1-21). MIT Press, Cambridge, Massachusetts.

Bodí, M. B., Martin, D. A., Balfour, V. N., Santín, C., Doerr, S. H., Pereira, P., Cerda, A., \& Mataix-Solera, J. (2014). Wildland fire ash: Production, composition and eco-hydro-geomorphic effects. Earth-Science Reviews, 130, 103-127. http://dx.doi.org/10.1016/j.earscirev.2013.12.007

Bond, W., \& Keeley, J. (2005). Fire as a Global 'Herbivore': The Ecology and Evolution of Flammable Ecosystems ». Trends in Ecology \& Evolution, 20(7), 387-394. https://doi.org/10.1016/j.tree.2005.04.025

Byram, G. M. (1959). Combustion of forest fuels. In: K. P. Davis (Ed.), Forest fire: control and use (pp. 61-89). New York: Mc Graw-Hill.

Cech, P. G. (2008). Impact of fire, large herbivores and N2-fixation on nutrient cycling in humid savanna, Tanzania (Unpublished doctoral dissertation). Swiss federal institute of technology zurich, Swiss.

Cook, G. D. (1994). The fate of nutrients during fires in a tropical savanna. Australian Journal of Ecology, 19, 359-365. https://doi.org/10.1111/j.1442-9993.1994.tb00501.x

Coutinho, L. M. (1990). Fire in the ecology of the Brazilian Cerrado. In J. G. Goldammer (Ed.), Fire in the Tropical Biota (pp. 82-105). Springer-Verlag, Berlin. 
Crutzen, P. J., Andreae, M. O. (1990). Biomass burning in the tropics: Impact on atmospheric chemistry and biogeochemical cycles. Science, 250, 1669-1678. DOI:10.1126/science.250.4988.1669

Daniell, J. W., Chappell, W. E., \& Couch, H. B. (1969). Effect of sublethal and lethal temperature on plant cells. Plant Physiology, 44, 1684-1689. https://doi.org/10.1104/pp.44.12.1684

Devineau, J. L., Lecordier, C., \& Vuattoux, R. (1984). Évolution de la diversité spécifique du peuplement ligneux dans une succession préforestière de colonisation d'une savane protégée des feux (Lamto, Côte d'Ivoire). Candollea, 39, 103-134. Retrieved from https://hal.archives-ouvertes.fr/hal-00434947

Ellicott, E., Vermote, E., Giglio, L., \& Roberts, G. (2009). Estimating biomass consumed from fire using MODIS FRE. Geophysical Research Letters, 36, 1-5. https://doi.org/10.1029/2009GL038581

Fernández, A. C., \& Carballas, T. (1997). Organic matter changes immediately after a wildfire in an atlantic forest soil and comparison with laboratory soil heating. Soil Biology and Biochemistry, 29, 1-11. https://doi.org/10.1016/S0038-0717(96)00289-1

Gautier L. (1990). Contact forêt-savane en Côte d'Ivoire centrale : Evolution du recouvrement ligneux des savanes de la réserve de Lamto (sud du V baoulé). Candollea., 45, 627-641.

Gignoux, G., Mordele, P., \& Menaut, J. C. (2006). Biomass Cycle and Primary Production. In L. Abbadie, J. Gignoux, , X. Le Roux, \& M. Lepage (Eds.), Structure, Functioning, and Dynamics of a savanna Ecosystem (pp. 115-137). New York: Springer-Verlag.

Helas, G., Lobert, J., Dieter Scharffe, D., Schäfer, L., Goldammer, J., Baudet, J., Ajavon, A-L., Ahoua, B., Lacaux, J-P., Delmas, R., \& Andreas, M. O. (1995). « Airborne measurements of savanna fire emissions and the regional distributio of pyrogenic pollutants over Western Africa ». Journal of atmospheric chemistry, 22(1-2), 217-239. https://doi.org/10.1007/BF00708190

Heubes, J., Kühn, I., König, K., Wittig, R., Zizka, G., \& Hahn, K. (2011). Modelling biome shifts and tree cover change for 2050 in West Africa. Journal of Biogeography, 38, 2248-2258. https://doi.org/10.1111/ j.1365-2699.2011.02560.x

Hoffmanna, W. A., Jaconis, S., Mckinley, K. L., Geiger, E. L., Gotsch, S. G., \& Franco, A. C. (2012). Fuels or microclimate? Understanding the drivers of fire feedbacks at savanna-forest boundaries. Austral Ecology, 37, 634-643. https://doi.org/10.1111/j.1442-9993.2011.02324.x

Högberg, P. (1986). Nitrogen-fixation and nutrient relations in savanna woodland trees (Tanzania). Journal of Applied Ecology, 23, 675-688. https://doi.org/10.2307/2404045

Innes, R. R. (1972). Fire in West African Vegetation. In: Tall Timbers Fire Ecology Conference, 11, $147-173$.

IPCC. (2002). Retrieved from www.ipcc.ch

Kauffman, J. B., Cummings, D. L., Ward, D. E., \& Babbitt, R. (1995). Fire in the Brazilian Amazon: 1. Biomass, nutrient pools, and losses in slashed primary forests. Oecologia, 104, 397-408. https://doi.org/10.1007/ BF00341336

Kidnie, S., \& Wotton, B. M. (2015). Characterisation of the fuel and fire environment in southern Ontario's tallgrass prairie. International Journal of Wildland Fire, 24, 1118-1128. https://doi.org/10.1071/WF14214

Koné, M. (2012). Up in smoke: biomass burning and atmospheric emissions in the sudanian savanna of Côte d'Ivoire (Unpublished doctoral dissertation). University of Illinois, Urbana-Champaign, USA.

Koné, W. A., Tondoh, E. J., Angui, K. T. P, Bernhard-Reversat, F., Loranger-Merciris, G., Brunet, D., \& Bre'doumi, K. T. S. (2008). Is soil quality improvement by legume cover crops a function of the initial soil chemical characteristics? Nutrient Cycling in Agrosystems, 82, 89-105. https://doi.org/10.1007/s10705-008 $-9172-4$

Laclau, J-P., Sama-Poumba, W., Nzila, J.D., Bouillet, J-P., \& Ranger, J. (2002). Biomass and nutrient dynamics in a littoral savanna subjected to annual fires in Congo. Acta Oecologica, 23, 41-50. https://doi.org/10. 1016/S1146-609X(02)01132-3

Le Roux, X. (1995). Survey and modelling of water and energy exchanges between soil, vegetation and atmosphere in a Guinea savanna (Unpublished doctoral dissertation). Université of Paris 6, France.

Liousse, C., Andreae, M. O., Artaxo, P., Barbosa, P., Cachier, H., Grégoire, J. M., ... Schultz, M. G. (2004). Deriving global quantitative estimates for spatial and temporal distributions of biomass burning emissions. 
In C. Granier, P. Artaxo, C.E. Reeves (Eds.), Emissions of atmospheric trace compounds (pp. 77-120). Kluwer Academic: Dordrecht, the Netherlands.

Ludwig, F., de Kroon, H., Berendse F., \& Prins H. H. T. (2004). The influence of savanna trees on nutrient, water and light availability and the understorey vegetation ». Plant Ecology, 170(1), 93-105. https://doi.org/10.1023/B:VEGE.0000019023.29636.92

Mackensenn, J., Hölscher, D., Klinge, R., \& Foölster, H. (1996). Nutrient transfer to the atmosphere by burning of debris in eastern Amazonia. Forest Ecology and Management, 86, 121-128. https://oi.org/10.1016/ S0378-1127(96)03790-5

Medina, E. (1987). Nutrients: requirements, conservation and cycles in the herbaceous layer. In B. H Walker (Ed.), Determinants of tropical savanna (pp. 39-65). IRL Press, Oxford.

Menaut, J-C., Abbadie, L., \& Vitousek, P. M. (1993). Nutrient and organic matter dynamics in tropical ecosystems. In: P. J Crutzen, J. G. Gold-hammer (Eds.), Fire in the environment: the ecological, atmospheric, and climatic importance of fires (pp. 215-231). Wiley, Chichester.

Murphy, J., \& Riley, J. P. (1962). A modified single solution method for the determination of phosphate in natural waters. Analytica Chimica Acta, 27, 31-36. https://doi.org/10.1016/S0003-2670(00)88444-5

N’Dri, A. B, Gignoux, J., Dembélé, A., \& Konaté, S. (2012). Short term effects of fire intensity and fire regime on vegetation dynamic in a tropical humid savanna (Lamto, central Côte d'Ivoire). Natural Science, 4(12), 1056-1064. https://doi.org/10.4236/ns.2012.412134N'Dri, A. B, Fongbe, M., Soro, T. D., Gignoux, J., Koné, M., Dosso, K., N'Dri, J. K., Koné, N. A., \& Barot, S (2018b). Principaux indices de l'intensité du feu dans une savane Guinéenne d'Afrique de l'ouest. Int. J. Biol. Chem. Sci. 12(1): 266-274. DOI : https://dx.doi.org/10.4314/ijbcs.v12i1.21

N’Dri, A. B., Koné, A. W., Loukou, S. K. K., Barot, S., \& Gignoux, J. (2018c). Carbon and nutrient losses through biomass burning, and links with soil fertility and yam (Dioscorea alata) production. Experimental Agriculture, 1-14. https://doi.org/10.1017/S0014479718000327

N’Dri, A. B., Soro, T. D., Gignoux, J., Dosso, K., Koné, M., Koné, N. A., N’Dri, J. K., \& Barot, S. (2018a). Season affect fire behaviour in annually burned humid savanna of West Africa. Fire Ecology, 14:5, https://doi.org/10.1186/s42408-018-0005-9

NASA. (2005). Biomass burning. http://earthobservatory.nasa.gov/Features/BiomassBurning/printall.php.

Nelson, D. W., \& Sommers, L. E. (1982). Total carbon organic carbon and organic matter. In A. L. Page, R. H. Miller \& D. R. Keeny (Eds), Methods of soil analysis, Part 2. Agronomy monograph no9 (pp. 539-579). ASA/SSSA, Madison.

O’Connel, A. M., Grove, T. S., \& Lamb, D. (1981). The influence of fire on the nutrition of Australian forests. Proceedings of Australian Forest Nutrition Workshop (pp. 277-289). Camberra, CSIRO, Melbourne.

Pagney, P. (1988). Le climat de Lamto (Côte d'Ivoire). In M. Lamotte, J. L Tireford (Eds.), Le Climat de la Savane de Lamto (Côte d'Ivoire) et sa Place dans les climats de l'Ouest Africain (pp. 31-79). Travaux de Recherche des Chercheurs de Lamto, Côte d'Ivoire.

R Development Core Team. (2014). $R$ : a language and environment for statistical computing. $R$ Foundation for Statistical Computing. Vienna.

Raison, R., Khanna, P. K., \& Woods, P. V. (1985a). Mechanisms of elements transfer to the atmosphere during vegetation fires. Canadian Journal of Forest Research, 15, 132-140. https://doi.org/10.1139/x85-022

Raison, R., Khanna, P. K., \& Woods, P. V. (1985b). Transfer of elements to the atmosphere during low-intensity prescribed fires in three Australian subalpine eucalypt forests. Canadian Journal of Forest Research, 15, 657-664. https://doi.org/10.1139/x85-107

Reid, J. S., Koppmann, R., Eck, T. F., \& Eleuterio, D. P. (2005). A review of biomass burning emissions part II: intensive physical properties of biomass burning particles. Atmospheric Chemistry and Physics, 5, 799-825. https://doi.org/10.5194/acp-5-799-2005

Riou, G. (1974). Les sols de la savane de Lamto. Bulletin de Liaison des Chercheurs de Lamto, 1, 3-45.

Rossiter-Rachor, N. A., Setterfield, S. A., Douglas, M. M., Hutle, L. B., \& Cook, G. D. (2008). Andropogon gayanus (Gamba Grass) invasion increases fire-mediated nitrogen losses in the tropical savannas of Northern Australia. Ecosystems, 11, 77-88. https://doi.org/10.1007/s10021-007-9108-x 
Shi, Y., Matsunaga, T., Saito, M., Yamaguchi, Y., \& Chen, X. (2015). Comparison of global inventories of $\mathrm{CO}_{2}$ emissions from biomass burning during 2002-2011 derived from multiple satellite products. Environmental Pollution, 206, 479-487. https://doi.org/10.1016/j.envpol.2015.08.009

Trollope, W. S. W. (1983). Control of bush encroachment with fire in the arid savannas of south-eastern Africa. (Unpublished doctoral dissertation). University of Natal, Pietermaritzburg.

Tunved, P., Hansson, H-C., Kerminen, V-M., Ström, J., Dal Maso, M., Lihavainen, H., Viisanen, Y., Aalto, P. P., Komppula, M., \& Kulmala, M. (2006). High natural aerosol loading over boreal forests. Science, 312, 261-263. https://doi.org/10.1126/science.1123052

Villecourt, P., Schmidt, W., \& Cesar, J. (1980). Perte d'un écosystème à l'occasion du feu de brousse (savane tropicale de Lamto cote d'Ivoire). Revue d'Ecologie et Biologie du sol, 17, 7-12.

\section{Copyrights}

Copyright for this article is retained by the author(s), with first publication rights granted to the journal.

This is an open-access article distributed under the terms and conditions of the Creative Commons Attribution license (http://creativecommons.org/licenses/by/4.0/). 